\title{
SYSTEMATIC LITERATURE REVIEW: KOMITMEN DAN KEPUASAN KERJA TERHADAP KINERJA KADER PUSKESMAS
}

\section{A SYSTEMATIC LITERATURE REVIEW: COMMITMENT AND JOB SATISFACTION TOWARDS THE PERFORMANCE OF PUBLIC HEALTH CENTRE CADRES}

\author{
${ }^{1}$ Hesty Yuliasari, ${ }^{2}$ Reni Merta Kusuma \\ 1,2 Departement of Psychology, Jenderal Achmad Yani Yogyakarta University/ \\ hestyyuliasari.psi@yahoo.com
}

\begin{abstract}
Introduction Public health promotion and monitoring carried out by community-assisted health center managers. The community is given the understanding that health efforts need to be made by all parties, both from the government and the community. Cadres are people who are formed to play an important role and have a strong commitment and dedication to move the organization to realize its vision and mission. Cadres are expected to have work commitment and satisfaction with their performance.
\end{abstract}

\begin{abstract}
Method This study aims to identify the commitment and job satisfaction of cadres to the performance of community health center cadres. The method used in this research is Systematic Literature Review (SLR) of journal papers published from 2010-2020.
\end{abstract}

Results Articles that did not match the inclusion criteria were issued, leaving 63 articles relevant for quality results, so the researchers screened the articles again by applying the PICOC criteria. There were 13 articles which showed that they constituted 21 percent of 63 articles or it could be said that only 11 percent of the total 116 articles found in the online database search. Based on the results of literature analysis on selected journals as many as 13 journals, each variable has a coverage proportion of $53.8 \%$ for job satisfaction, $53.8 \%$ for commitment to organization and $46.15 \%$ for performance variables. In the variable job satisfaction the proportion of 53.8\%, namely 7 journals from 13 selected journals that discuss job satisfaction.

Conclusions and Recommendation The active role of cadres on job satisfaction shows the cadre's performance and the implementation of self-commitment and work commitment related to the health center. Commitment of cadres can be seen in their affective commitment to the organization where the increased performance of cadres is not only based on incentives, but the existence of self-development and increasing knowledge will increase cadre performance.

Keywords: Commitment, Job satisfaction, Job performance, Public health center cadres

\begin{abstract}
ABSTRAK
Pendahuluan Promosi dan pemantauan kesehatan masyarakat dilakukan oleh pengelola puskesmas binaan masyarakat. Masyarakat diberi pemahaman bahwa upaya kesehatan perlu dilakukan oleh semua pihak, baik dari pemerintah maupun masyarakat. Kader adalah orangorang yang dibentuk untuk memegang peranan penting dan memiliki komitmen dan dedikasi yang kuat untuk menggerakkan organisasi guna mewujudkan visi dan misinya. Kader diharapkan memiliki komitmen kerja dan kepuasan terhadap kinerjanya.
\end{abstract}

Metode Penelitian ini bertujuan untuk mengetahui komitmen dan kepuasan kerja kader terhadap kinerja kader puskesmas. Metode yang digunakan dalam penelitian ini adalah systematic literature review (SLR) artikel jurnal yang diterbitkan tahun 2010-2020 dengan kriteria PICOC. 
Hasil Menyisakan 13 artikel yang mana menunjukkan bahwa artikel-artikel tersebut merupakan 21 persen dari 63 artikel atau bisa dikatakan hanya 11 persen dari total 116 artikel yang ditemukan dalam pencarian database online. Berdasarkan hasil analisis literatur pada jurnal terpilih sebanyak 13 jurnal, masing-masing variabel memiliki persentase cakupan sebesar 53,8 $\%$ untuk Kepuasan kerja, 53,8\% untuk komitmen terhadap organisasi, dan 46,15\% untuk variabel kinerja. Pada variabel kepuasan kerja persentase sebesar 53,8 \% yaitu 7 jurnal dari 13 jurnal terpilih yang membahas mengenai kepuasan kerja.

Kesimpulan dan Saran Adanya peran aktif kader dalam mencapai kepuasan kerjanya menunjukkan kinerja kader dan implementasi terhadap komitmen diri maupun komitmen kerja berkaitan dengan puskesmas. Komitmen kader terlihat dalam komitmen afektifnya terhadap organisasi dimana kinerja kader yang meningkat tidak hanya berdasarkan insentif, namun adanya pengembangan diri dan peningkatkan pengetahuan akan meningkatkan kinerja kader

Kata kunci: Komitmen, Kepuasan kerja, Kinerja , Kader Puskesmas

\section{Pendahuluan}

Puskesmas menjalankan tugas promosi dan pelayanan kesehatan berbasis masyarakat. Promosi dan monitoring kesehatan masyarakat yang dilakukan oleh pengelola puskesmas dibantu masyarakat. Masyarakat diberi pemahaman bahwa upaya kesehatan perlu diusahakan dari semua pihak baik dari pemerintah maupun masyarakat.

Kader adalah orang yang dibentuk untuk memegang peran penting dan memiliki komitmen serta dedikasi kuat untuk menggerakkan organisasi dalam mewujudkan visi misinya. Kader dibekali dan didampingi dalam rangka meningkatkan pengetahuan, sikap, keterampilan, perilaku, kemampuan, kesadaran, serta manfaat sumber daya melalui penetapan kebijakan, program, kegiatan, dan pendampingan yang sesuai dengan esensi masalah dan prioritas kebutuhan masyarakat daerah setempat (Ghozali, 2015).

Tugas kader salah satunya menjadi agen kesehatan di masyarakat atau sebagai perpanjangan tangan dari puskesmas guna mendeteksi dini dan melaporkan kepada pihak puskesmas. Hal ini membuat kader juga memiliki intensitas yang tinggi untuk dapat melakukan kontak dan tatap muka dengan masyarakat di wilayah. Intensitas dan peran kader dalam menjalankan tugasnya akan terlihat sebagai kinerja kader puskesmas.
Kinerja adalah hasil kerja yang dapat dicapai oleh seseorang atau sekelompok orang dalam suatu organisasi, sesuai dengan wewenang dan tanggung jawab masing-masing dalam rangka upaya mencapai tujuan organisasi yang bersangkutan secara legal, tidak melanggar hukum dan sesuai dengan moral maupun etika. Usaha untuk meningkatkan kinerja, di antaranya dengan memperhatikan lingkungan kerja.

Lingkungan kerja merupakan sesuatu yang ada di sekitar para pekerja yang dapat mempengaruhi dirinya dalam menjalankan tugas-tugas yang dibebankan (Nitisemito, dalam Prihantoro, 2015). Beberapa penelitian menjelaskan bahwa kinerja dipengaruhi oleh banyak faktor, baik secara internal ataupun eksternal. Secara internal, kader yang mampu meningkatkan kinerjanya akan memiliki keterikatan terhadap tugas yang akan dilakukannya, sehingga memberikan komitmen terhadap tanggung jawab yang diberikan.

Luthans (1995) dalam Prihantoro (2015) menyatakan bahwa komitmen organisasional (organizational commitment) atau komitmen kerja merupakan tingkat keyakinan pekerja untuk menerima tujuan organisasi sehingga berkeinginan untuk tetap tinggal dan menjadi bagian dari organisasi tersebut. Pekerja yang berkomitmen cenderung lebih bertanggungjawab dalam memberikan pelayanan. Istilah pekerja dalam konteks 


\section{Systematic Literature Review: Komitmen dan Kepuasan Kerja Terhadap Kinerja Kader Puskesmas}

usaha kesehatan berbasis masyarakat yangadalah kader karena posisi yang penting inilah, komitmen kerja kader penting untuk dinilai.

Kader yang memiliki komitmen yang tinggi akan merasa puas akan bidang kerjanya, supervisi, insentif ataupun interaksi dengan sesama kader lainnya dan masyarakat yang dilayani. Masyarakat dalam konteks kinerja kader, salah satunya ibu-ibu yang datang ke Posyandu untuk menimbangkan berat badan anaknya, memantau pertumbuhan, dan perkembangan anak di posyandu.

Kepuasan kerja dalam penelitian ini adalah masyarakat yang dilayani oleh kader (Bahri, 2018). Pelayanan yang diberikan sesuai harapan atau tidak. Kepuasan kerja adalah sikap emosional yang menyenangkan dan mencintai pekerjannya.

Dalam mencapai visi dan misi program puskesmas, maka puskesmas menginginkan kontribusi maksimal dari kader diukur berdasarkan kinerja yang memuaskan. Hal ini menuntut kader agar mampu memberikan kinerja terbaiknya melalui kreativitas, integritas, komitmen dan kemampuan yang dimiliki.

Dalam ruang lingkup organisasi, Kader merupakan pekerja yang bertanggung jawab pada organisasinya. Kinerja sangat berperan dalam pertumbuhan organisasi dan profitabilitas organisasi. Penelitian Omolayo, \& Oluwafemi (2012) menegaskan bahwa efektivitas dan efisiensi organisasi tergantung pada seberapa efektif dan efisien karyawan berfungsi dalam organisasi.

Penelitian yang dilakukan oleh Bakan, Buyukese, Ersahan dan Sezer (2019) menemukan bahwa 36,7 persen kepuasan kerja mempengaruhi kinerja, sedangkan 28,7 persen komitmen terhadap pekerjaan mempengaruhi kinerja, meskipun persentase cukup kecil, namun hal itu membuktikan kinerja dipengaruhi oleh kepuasan dan komitmen. Penelitian Inuwa (2015) menjelaskan pekerja dengan tingkat kinerja tinggi cenderung lebih efisien dan efektif dalam menjalankan perannya masing-masing.

Peneliti memiliki ketertarikan pada topik pengaruh komitmen kerja dan kepuasan kerja terhadap kinerja kader Puskesmas, dengan maksud untuk melihat sejauh mana komitmen dan kepuasan kader Puskesmas dalam mengemban tugasnya. Diharapkan data yang diperoleh dapat menjadi landasan program intervensi lanjutan untuk kegiatan pengembangan pengetahuan dan keterampilan kader di Puskesmas.

\section{Komitmen}

Komitmen dalam penelitian ini mengarah pada komitmen kerja. Komitmen kerja merupakan istilah lain dari komitmen organisasional yang merupakan dimensi perilaku yang dapat digunakan untuk menilai kecenderungan pegawai. Komitmen organisasional merupakan sikap yang menunjukkan loyalitas seseorang bisa jadi karyawan dan merupakan proses berkelanjutan seorang anggota organisasi mengekspresikan perhatian pada kesuksesan dan kebaikan organisasinya (Prinhantoro, 2015).

Komitmen kerja memiliki dua komponen penting, yaitu sikap dan kehendak untuk bertingkah laku terhadap suatu perkara. Sikap berkaitan dengan identifikasi, keterlibatan dan kesetiaan, sedangkan kehendak bergantung pada keadaan untuk bertingkah laku dalam kesediaan menampilkan usaha.

Allen dan Meyer (1993) dalam Prihantoro (2015) mengungkapkan bahwa terdapat tiga model komitmen organisasional, antara lain:

a. Komitmen afektif (affective commitment). Aspek ini, merupakan perasaan emosional dan keyakinankeyakinan dari anggota terhadap nilainilai dan tujuan dari organisasi/ instansi.

b. Komitmen berkelanjutan (continuance commitment). Aspek ini berkaitan dengan nilai ekonomis yang didapat seorang, yang berarti bahwa seseorang 
memilih bertahan pada suatu organisasi/ pekerjaan karena mendapat keuntungan-keuntungan tertentu.

c. Komitmen normatif (normative commitment)

Aspek ini berkaitan dengan keinginan untuk bertahan dengan organisasi/ instansi/ pekerjaannya untuk alasanalasan moral dan etis.

\section{Kepuasan Kerja}

Noermijati (2013) dan Fattah (2017) mendefinisikan kepuasan kerja sebagai perasaan positif tentang pekerjaan sebagai hasil evaluasi karakter-karakter pekerjaan tersebut. Kepuasan kerja merupakan salah satu aspek psikologis yang mencerminkan perasaan seseorang terhadap pekerjaannya, seseorang akan merasa puas dengan adanya kesesuaian antara kemampuan, keterampilan, dan harapannya dengan pekerjaannya (Hamirul, 2016).

Di dalam Noermijati (2013) dan Robbins dan Judge (2010) terdapat beberapa faktor yang memberikan kepuasan kerja terhadap karyawan yaitu pekerjaan itu sendiri (Work It self), gaji/Upah (Pay), promosi (Promotion), atasan (Supervision) dan rekan kerja (Workers).

\section{Kinerja}

Kinerja adalah wujud hasil kerja yang dihasilkan oleh seseorang. Kinerja digunakan sebagai penilaian atau evaluasi sistem yang merupakan kekuatan penting terhadap perilaku seseorang (Robbins dan Judge, 2010). Selain itu, Robbins dan Judge juga menyebutkan enam indikator untuk mengukur kinerja secara individu yaitu kualitas kerja, kuantitas hasil kerja, ketepatan waktu, efektivitas sumber daya, kemandirian, dan komitmen kerja.

Pengaruh komitmen kerja dan kepuasan kerja terhadap kinerja kader Puskesmas diungkapkan dalam penelitian Sukmawati dan Gani (2014) bahwa terjadinya keterkaitan variabel kepuasan kerja dan komitmen organisasional dapat memberikan pengaruh secara langsung terhadap kinerja karyawan. Terdapat juga bukti bahwa komitmen karyawan berhubungan dengan hasil lain yang diinginkan, seperti persepsi iklim organisasi yang hangat dan mendukung, serta menjadi anggota tim yang baik yang siap membantu (Novita dkk, 2016)

\section{Metode}

Metode penelitian dengan Systematic Literature Review. Sumber data diambil hasil publikasi penelitian yang berhubungan dengan topik yaitu terkait dengan komitmen kerja, dan kepuasan terhadap kinerja kader. Hasil publikasi diambil jurnal nasional terakreditasi Sinta dan jurnal internasional.

\section{Research Question.}

Pertanyaan penelitian berdasarkan kebutuhan dari topik yang dipilih.
RQ1. Apa faktor-faktor yang mempengaruhi komitmen dan kepuasan kerja terhadap kinerja kader puskesmas dalam penelitian 2010-2020?

RQ2. Apa metode yang digunakan untuk meningkatkan kinerja kader puskesmas?

\section{Kriteria Penelitian}

Kriteria inklusi, yaitu artikel memiliki syarat sesuai yang ditentukan oleh peneliti sebagai berikut:

a. Artikel dapat ditelusuri secara online terindeks Sinta

b. Artikel terkait topik penelitian maksimal 10 tahun yaitu tahun 20102020

Adapun kriteria eksklusif yaitu artikel yang sudah memiliki kriteria inklusi namun ada keadaan yang harus dikeluarkan, yaitu:

a. Artikel yang tidak jelas alur penelitiannya

b. Artikel yang tidak ada identitasnya

\section{Tahap Penelitian}

Penelitian systematic review ini terdiri dari beberapa langkah yang harus dilalui menurut Wahono (2015), yaitu planning, 


\section{Systematic Literature Review: Komitmen dan Kepuasan Kerja Terhadap Kinerja Kader Puskesmas}

conducting, dan reporting. Penjelasannya peneliti jelaskan sebagai berikut:

a. Planning

Pada tahap ini, dimulai dengan memformulasikan pertanyaanpertanyaan yang dipakai untuk penelitian yang mau dilakukan review berdasarkan PICOC, Istilah PICOC merupa singkatan dari istiah-istilah di bawah ini:

1) Population (P) yaitu target grup dari investigasi atau penelusuran artikel hasil penelitian. Populasi dalam penelitian ini adalah kader.

2) Intervention (I) berupa aspek detail dari investigasi atau isu yang menarik bagi peneliti.

3) Comparison (C) berupa aspek dari investigasi yang membandingkan antar intervensi yang dilakukan dari hasil penelitian.

4) Outcomes $(\mathrm{O})$ berupa efek dan hasil intervensi yang telah dituliskan dan telah dipublikasikan. Ada hasil komitmen kerja, kepuasan,dan kinerja kader.

5) Context (C) berupa setting dan lingkungan dari investigasi di wilayah kerja puskesmas.

\section{b. Conducting}

Tahapan conducting adalah tahap pelaksanaan penelitian systematic review dengan melaksanakan langkahlangkah berikut:

1) Penentuan kata kunci dari pencarian literatur dengan menggunakan kata kunci kader, petugas kesehatan masyarakat, petugas kesehatan komunitas, kepuasan kerja, komitmen kerja, dan kinerja kader

2) Penentuan sumber pencarian literatur (digital library) yang dikelola dengan literature software endnote

3) Pemilihan literatur yang sesuai dengan topik penelitian dibantu dengan kriteria inklusi dan eksklusi penelitian.
4) Penilaian kualitas literatur (quality assessment) dengan rekomendasi berdasarkan parameter pertanyaan yang bisa diajukan (Kitchenham dalam Wahono, 2016)

5) Pelaksanaan ekstraksi data (data extraction) dengan membuat pengelompokkan hasil artikel yang ditemukan

6) Penindaklanjutan ekstrasi data dengan melakukan sintesis literatur-literatur yang sudah dipilih (synthesis of evidence) secara naratif dan kuantitatif.

\section{c. Reporting}

Tahap reporting merupakan tahap penulisan hasil dari penelitian systematic review yang disusun dalam bentuk tulisan.

\section{Hasil}

Berdasarkan hasil tahapan metode sistematik review menurut Wahono (2016) bahwa melalui tiga tahapan seleksi, yaitu planning, conducting, dan reporting. Pada tahap pertama, peneliti melakukan pencarian digital dan melakukan seleksi proses berdasarkan judul yang menghasilkan 116 referensi yang dianggap relevan dengan variabel yang dicari.

Relevan atau tidaknya variabel berdasarkan kesesuaian dengan tujuan penelitian kemudian dijadikan satu, lalu dilakukan screening apakah judul pada artikel tersebut ada yang sama atau tidak. Selanjutnya, dilakukan evaluasi pada abstrak dan konten singkat dari artikel yang ditemukan dan dipilih. Saat melakukan evaluasi ditemukan 25 artikel yang termasuk dalam duplikat dan 28 artikel yang tidak relevan dengan kriteria inklusi. Artikel yang tidak sesuai dengan kriteria inklusi dikeluarkan sehingga menyisakan 63 artikel yang relevan untuk dilakukan penilaian kualitas.

Dari 63 artikel tersebut peneliti menyaring lagi dengan menerapkan kriteria PICOC dan menyisakan 13 artikel yang mana menunjukkan bahwa artikel-artikel 
tersebut merupakan 21 persen dari 63 artikel atau bisa dikatakan hanya 11 persen dari total 116 artikel yang ditemukan dalam pencarian database online. 13 artikel tersebut adalah artikel yang dilakukan sintesis data setelah penyaringan berdasarkan kriteria inklusi dan skrining rinci terhadap abstrak ataupun teks lengkap. Pada tahap selanjutnya dilakukan penelusuran dan pencarian sumber-sumber didapatkan analisis dari 13 jurnal tersebut menunjukkan 10 jurnal dengan metode kuantitatif dan cross-sectional survey, 1 jurnal dengan metode kuantitatif korelasional, 1 jurnal dengan Mixed methods (metode kuantitatif dan kualitatif) dan 1 jurnal dengan metode kualitatif. Literatur yang dikutip dalam tinjauan ini merupakan publikasi artikel yang terbit dari tahun 2010 hingga 2020. Jenis penelitian kuantitatif dari penelitian yang terpilih menggunakan metode survei melalui kuesioner-kuesioner jawaban skala likert, sedangkan untuk penelitian kualitatif menggunakan daftar pertanyaan panduan wawancara untuk mengumpulkan data . 


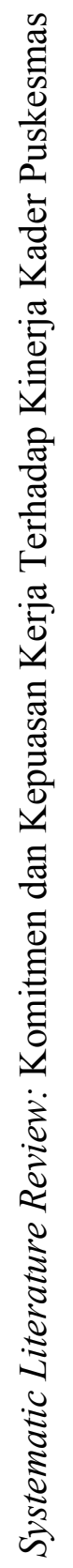

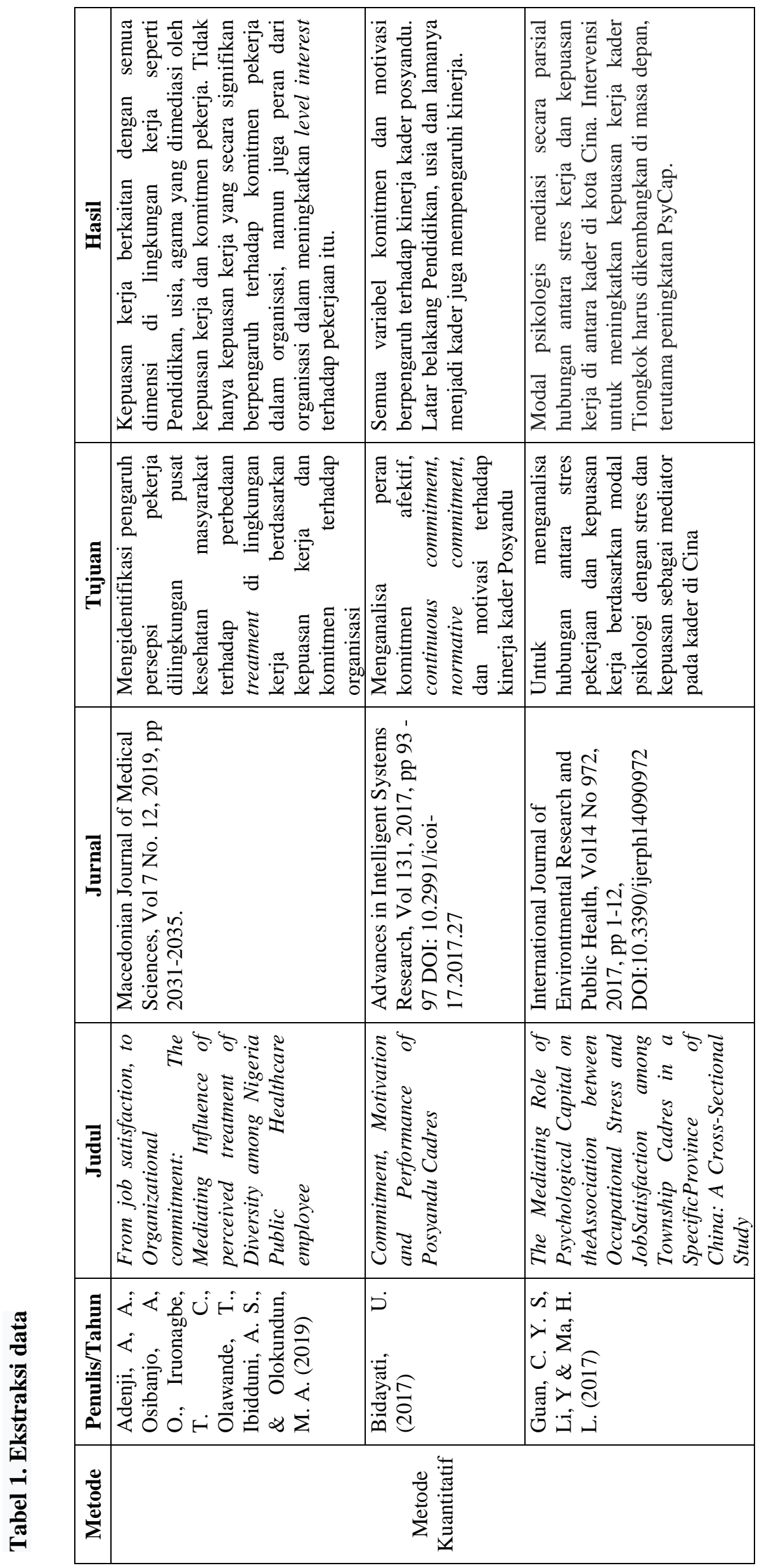

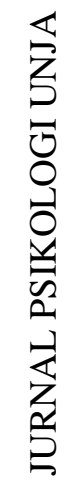




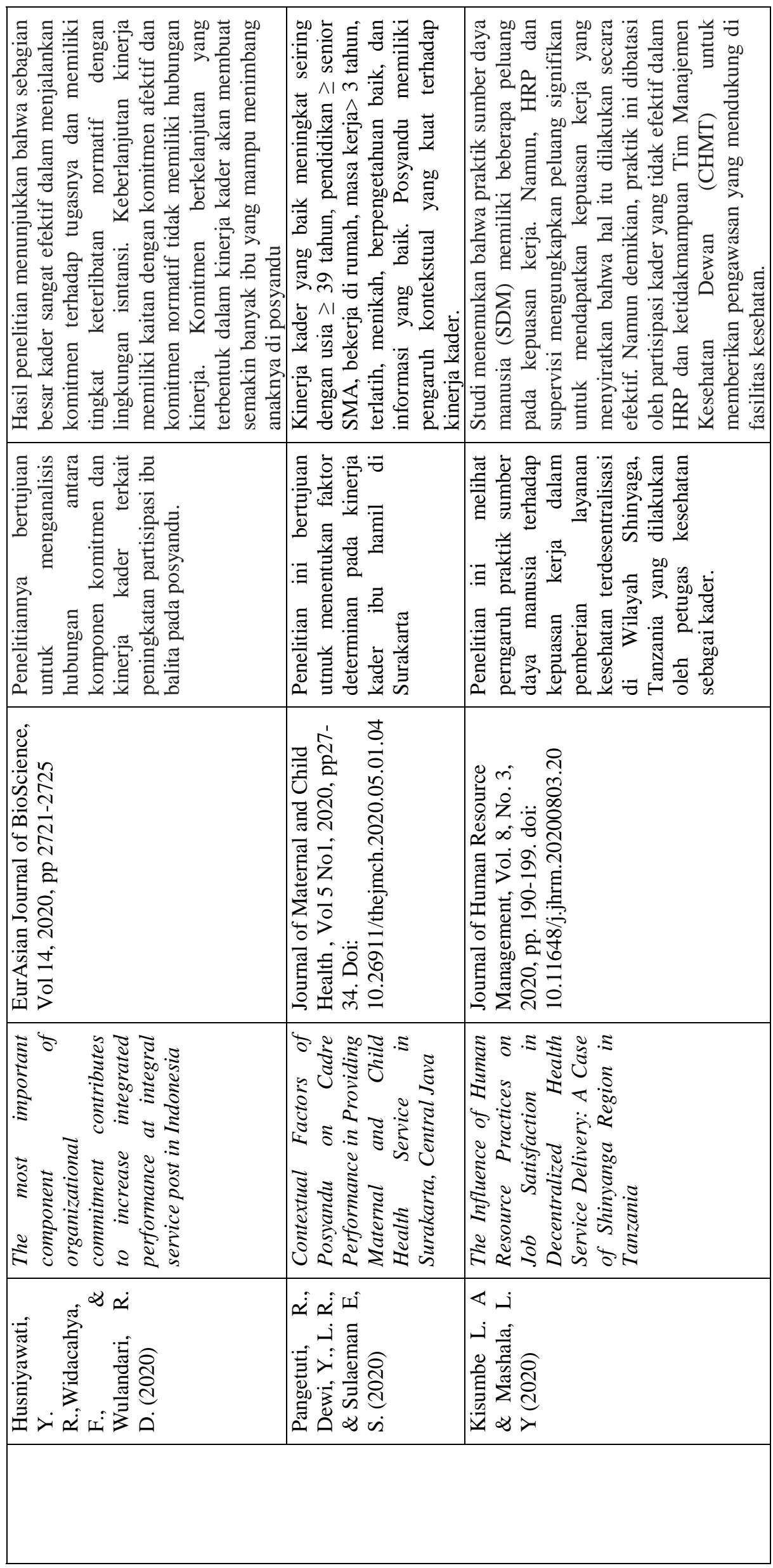




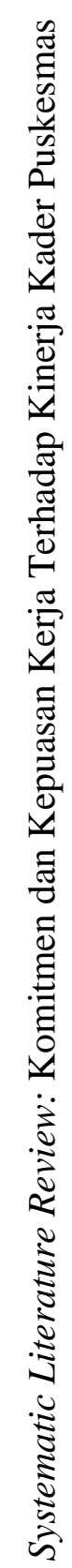

\begin{tabular}{|c|c|c|}
\hline 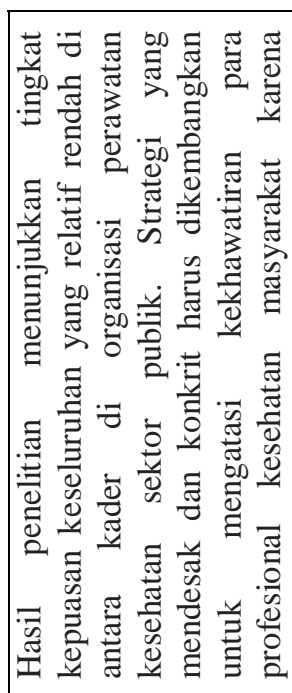 & 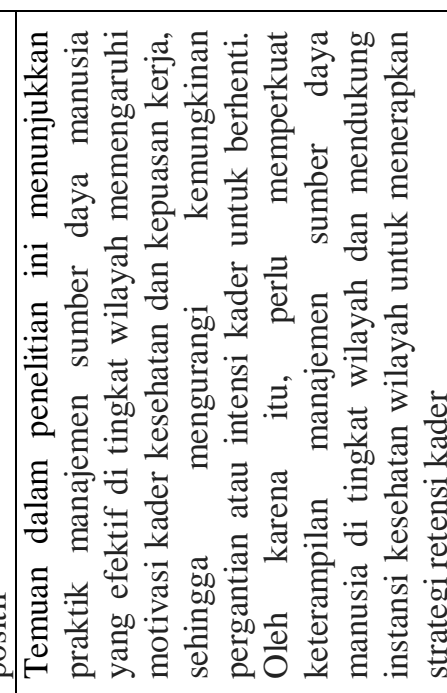 & 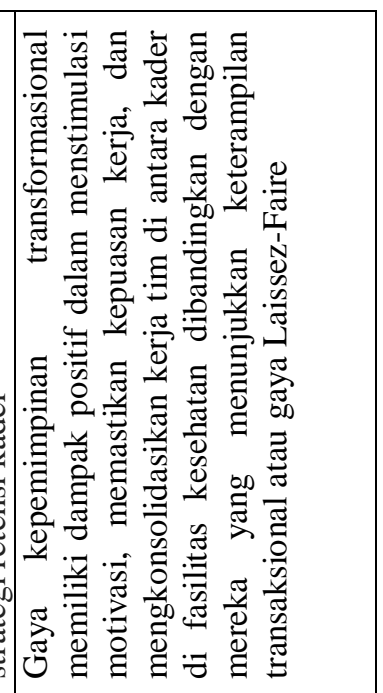 \\
\hline 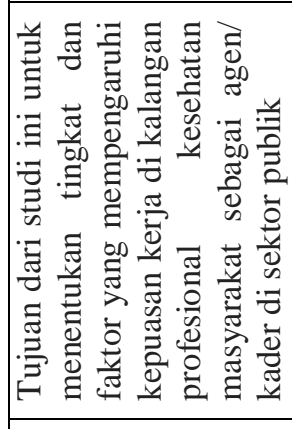 & 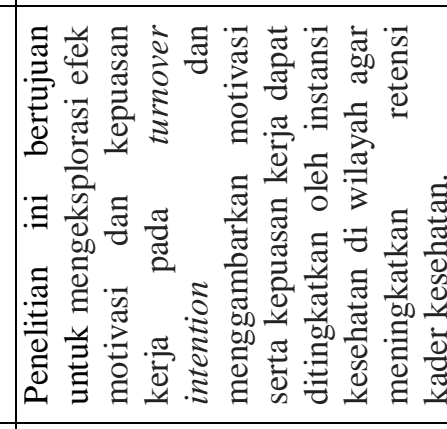 & 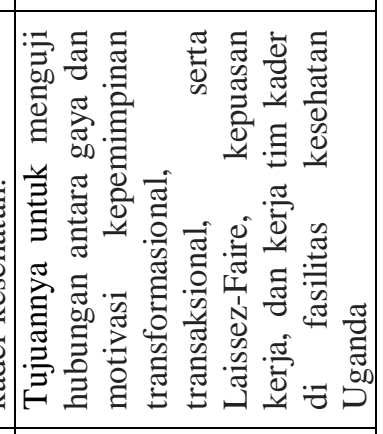 \\
\hline 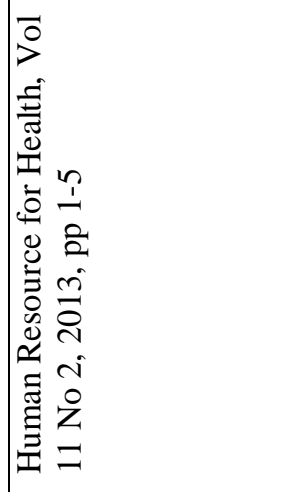 & 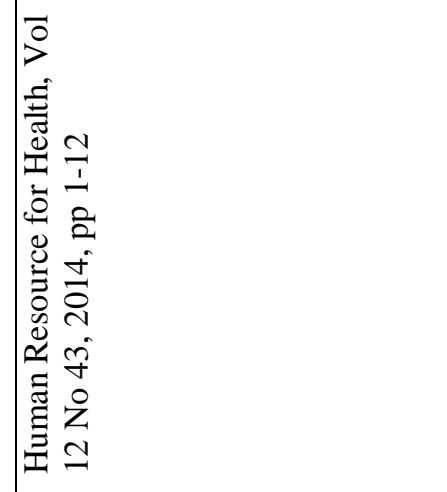 & 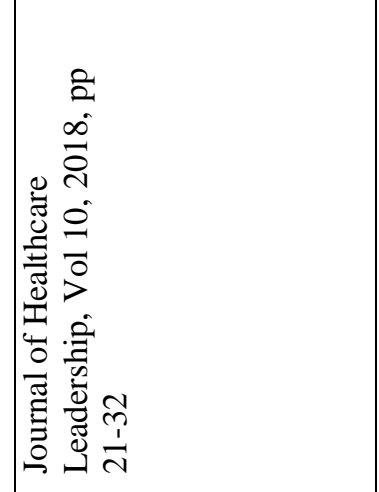 \\
\hline 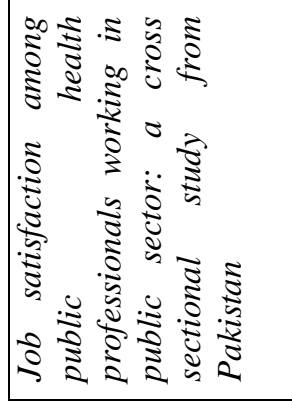 & 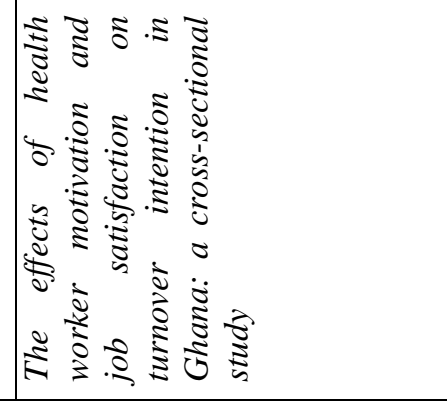 & 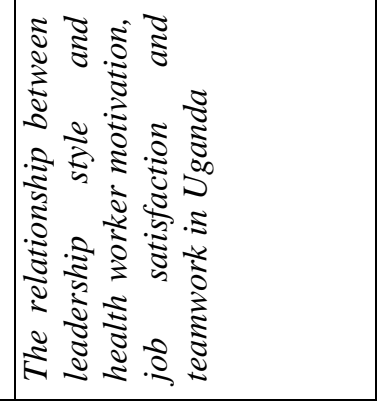 \\
\hline 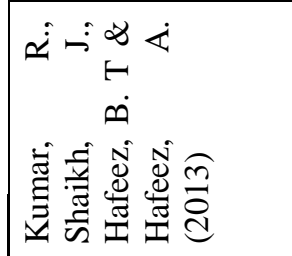 & 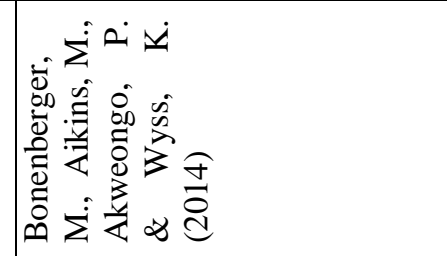 & 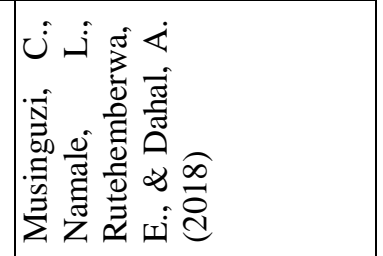 \\
\hline
\end{tabular}




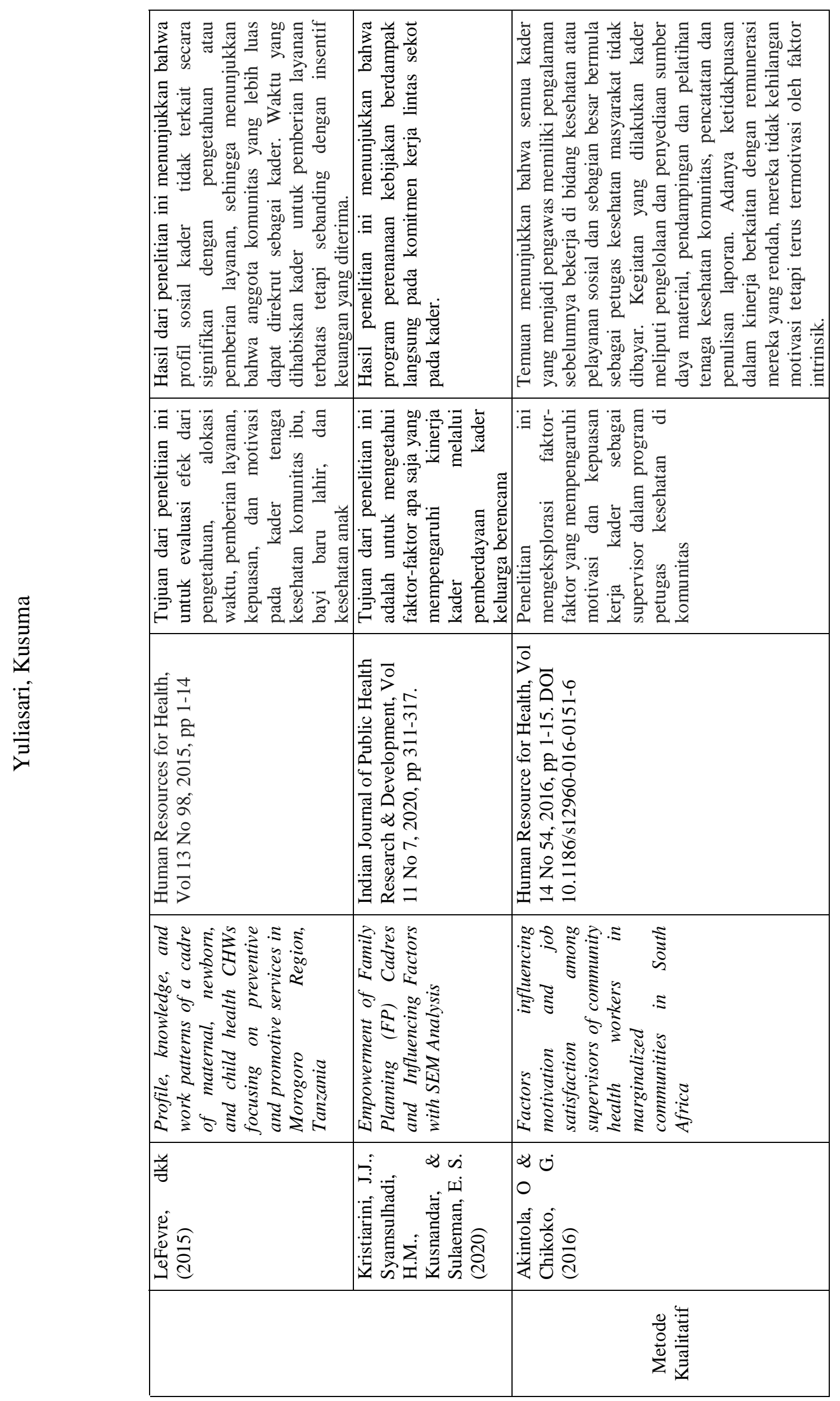




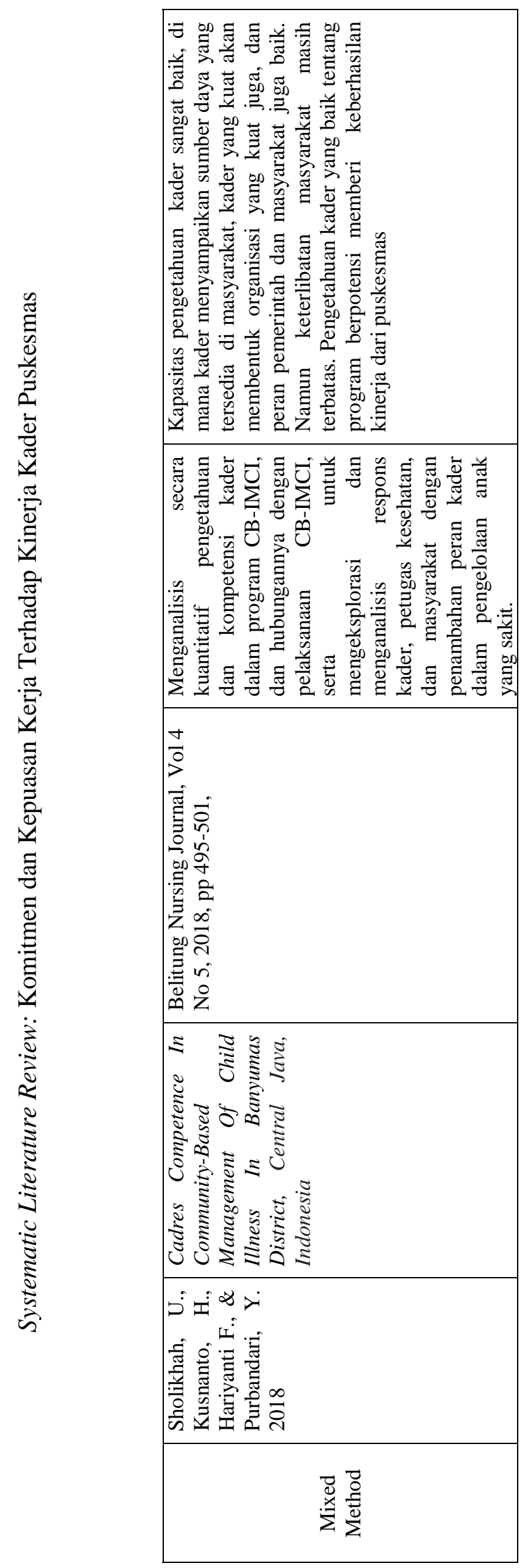




\section{Pembahasan}

Berdasarkan hasil analisis literatur pada jurnal terpilih sebanyak 13 jurnal, masing-masing variabel memiliki persentase cakupan sebesar 53,8 \% untuk Kepuasan kerja, 53,8\% untuk komitmen terhadap organisasi, dan 46,15\% untuk variabel kinerja. Pada variabel kepuasan kerja persentase sebesar 53,8\% yaitu 7 jurnal dari 13 jurnal terpilih yang membahas mengenai kepuasan kerja. Kepuasan kerja merupakan sikap seseorang terhadap pekerjaannya berdasarkan selisih antara banyaknya hal yang diterima dan banyaknya hal yang diyakini seharusnya diterimanya (Robbins \& Judge, 2010).

Kepuasan kerja individu berhubungan dengan ruang lingkup budaya, faktor internal individu tersebut dan lingkungan organisasi atau lingkungan kerjanya. Begitu pula dengan kader dan pekerja di bidang kesehatan komunitas, adanya keberagaman dalam situasi dan lingkungan kerja yang cenderung tidak monoton dapat meningkatkan kepuasan kerja pada petugas layanan kesehatan komunitas (Adenji, dkk, 2019). Hasil analisis literatur terhadap kepuasan kerja cukup banyak dibahas dalam ruang lingkup human development, namun untuk yang berkaitan tentang kepuasan kerja pada petugas kesehatan komunitas, kader ataupun pekerjaan yang sejenis tidak terlalu banyak ditemukan.

\begin{tabular}{llr}
\multicolumn{2}{c}{ Beberapa penelitian } & terhadap \\
kepuasan kerja berkaitan & dengan \\
demografis & petugas berupa & usia,
\end{tabular} Pendidikan, ataupun lamanya pengalaman sebagai kader kesehatan (Sholikhah dkk, 2018), motivasi (Akintola \& Chikoko, 2016), stres kerja (Guan, Li \& Ma, 2017) ataupun komitmen terhadap organisasi (Adenji, dkk 2019). Kepuasan kerja adalah fungsi dari perbedaan kinerja yang dirasakan dan harapan dari individu yang bekerja sehingga akan banyak pula variabel pendukung atau variabel resiko yang akan memberikan penurunan kepuasan kerja. Kepuasan kerja mencerminkan kepuasan seseorang terhadap organisasi sampai batas tertentu. Jika individu puas dengan organisasi maka akan menunjukkan peningkatan kinerja.

Kepuasan kerja yang semakin rendah dari pekerja kesehatan berdampak pada peningkatan pergantian staf dan ketidakhadiran yang berimbas pada efisiensi pelayanan kesehatan (Merga \& Fufa, 2019). Selain berdampak pada diri sendiri, tidak adanya kepuasan kerja akan berdampak pada performa dari institusi dalam pandangan pengguna jasa institusi tersebut. Adanya kepuasan kerja yang menunjukkan akan peningkatan efektif dalam kinerja kader, namun peningkatan kinerja tetap membutuhkan partisipasi kader secara penuh dalam hal manajemen dan peran tim manajemen kesehatan untuk dapat mengasai dukungan pada fasilitas kesehatan (Kisumbe \& Mashala, 2020)

Farooqui \& Nagendra (2014) menjelaskan bahwa partisipasi pekerja yang tidak efektif dalam pengembangan kemampuan pekerja kemungkinan akan menyebabkan ketidaksesuaian antara persyaratan dan pasokan sumber daya manusia. Rencana kerja tidak hanya cukup diinformasikan tentang kualitas dan kuantitas sumber daya manusia untuk berhasil, namun juga memenuhi konteks kebutuhan khusus masyarakat sehingga memberikan penilaian terhadap kepuasan kerja.

Para petugas kesehatan komunitas ataupun kader yang berusaha bekerja optimal memberikan peningkatan kepuasan kerja baik dari diri internal maupun dari pengguna layanan petugas tersebut. Adanya peningkatan kepuasan terhadap pekerjaannya membantu masyarakat menjadi lebih efektif dan menghargai pekerjaan petugas kesehatan komunitas ataupun kader, sehingga tercapainya tujuan dan target kerja petugas, membuat petugas merasa lebih bersyukur dengan pekerjaannya (Geldsetzer, De Neve, Boudreaux, Bärnighausen \& Bossert, 2017).

Pada variabel komitmen kerja persentase sebesar $53,8 \%$ yaitu 7 jurnal 


\section{Systematic Literature Review: Komitmen dan Kepuasan Kerja Terhadap Kinerja Kader Puskesmas}

dari 13 jurnal terpilih yang membahas mengenai komitmen kerja. Komitmen kader mengarah pada rasa tanggung jawab kader dan keterikatan kader terhadap lingkungan kerja maupun organisasi yang menaunginya. Penelitian dari Kristiarini, Syamsulhadi, Kusnandar, \& Sulaeman (2020) menunjukkan bahwa program perencanaan kebijakan berdampak langsung pada komitmen kerja lintas sektor pada kader.

Para kader dapat memaksimalkan kinerjanya jika adanya kebijakan yang mendukung kinerja. Seperti penelitian yang dilakukan oleh Hadiyanta, Istiyono, \& Pramantara (2016) yang mengatakan bahwa kebijakan pemerintah terhadap tercapai peran kader di masyarakat disesuaikan dengan panduan kader/ buku pintar kader. Hanya saja kebijakan tersebut cukup menyulitkan beberapa kader dikarenakan kemampuan untuk memahami buku pintar kader, sehingga peningkatan kinerja kader dapat dilakukan melalu peningkatan pemahaman dan pengetahuan berdasarkan media role play sehingga kader dapat lebih memahami cara kerja dan peran di masyarakat.

Penelitian yang dilakukan Sholikhah, dkk (2017) menunjukkan bahwa kapasitas pengetahuan kader sangat baik, di mana kader menyampaikan sumber daya yang tersedia di masyarakat, kader yang kuat akan membentuk organisasi yang kuat juga, dan peran pemerintah dan masyarakat yang juga baik. Husniawati, dkk (2020) menjelaskan sebagian besar kader sangat efektif dalam menjalankan komitmen terhadap tugasnya dan memiliki tingkat keterlibatan normatif dengan lingkungan instansi. Keberlanjutan kinerja memiliki kaitan dengan komitmen afektif dan komitmen normatif tidak memiliki hubungan kinerja. Hilaire \& Robertie (2018) berpendapat meningkatkan komitmen dalam organisasi menjadi penting karena adanya keterikatan secara afektif antara pelaku kerja dalam lingkungan kerja sehingga menikmati dan membangkitkan keinginan untuk tetap berada dalam organisasi kerjanya.

Pada variabel kinerja persentase sebesar 46,15\% yaitu 6 jurnal dari 13 jurnal terpilih yang membahas mengenai kinerja. Kinerja berkaitan dengan pemahaman kader ataupun petugas kesehatan komunitas dalam memahami tugas-tugasnya di lingkungan kerja sebagai bentuk implementasi deskripsi kerjanya. Kapasitas pengetahuan kader akan mendukung kinerja dari pekerja kesehatan sehingga secara tidak langsung juga menjadi tolak ukur kinerja kader. Kader yang kompeten memiliki komitmen untuk aktif mengimplementasikan pengetahuannya dalam melayani masayarakat.

Hal ini sejalan dengan penelitian Sihombing, Kandarina, dan Sumarni (2016) bahwa peran aktif kader sebagai wujud komitmen tugas meningkatkan minat masyarakat terlibat aktif dalam layanan kesehatan dan memberikan kontribusi terhadap tercapainya kinerja kader. Kriteria kader yang dapat diterima masyarakat tidak terbatas pada pengetahuan mengenai apa yang dikerjakan namun lebih pada interaksi sosial dalam masyarakat yang dibangun.

Peningkatan terhadap level interest pekerjaan juga dapat memberikan persamaan persepsi kader melalui komiten yang tinggi terhadap tujuan organisasinya. Kebutuhan untuk menghargai peran dari keragaman kapasitas masing-masing pekerja yang terlibat dalam organisasi akan berfungsi pula dalam peningkatan kinerja (Choi, 2013). Penelitian yang dilakukan oleh Pangetuti, Dewi, \& Sulaeman (2020) menjelaskan bahwa Kinerja kader yang baik meningkat seiring dengan usia, pendidikan SMA, bekerja di rumah, masa kerja, terlatih, menikah, berpengetahuan baik, dan informasi yang baik.

Perhatian publik dan pemerintah terhadap pekerjaan kader dalam memberikan layanan kesehatan, dapat meningkatkan komitmen dan motivasi kader. Peran masyarakat, tokoh masyarakat dan layanan kesehatan petugas di wilayah 
tersebut mendukung masyarakat dan peran pemerintah dalam menentukan keberhasilan dan kesinambungan kegiatan Posyandu (Wirapuspita, 2013). Hal ini didukung oleh hasil penelitian Bidayati (2017) menunjukkan bahwa kinerja kader dipengaruhi oleh komitmen dan motivasi kader terhadap perannya dalam meningkatkan kualitas kesehatan ibu hamil dan anak-anak. Kinerja kader Posyandu sangat penting bagi kualitas kesehatan ibu hamil dan anak-anak di bawah usia lima tahun.

Peningkatan kinerja kader maupun petugas kesehatan komunitas dapat dilakukan dengan melatih petugas secara berkesinambangun agar adanya peningkatan keterampilan terkait pekerjaannya. Adanya peningkatan kapasitas pengelolaan sumberdaya melalui pelatihan ataupun pembekalan pendidikan, maka akan meningkatkan kebersamaan dalam melakukan kegiatan kerja yang ditunjukkan dengan kerja sama dan peningkatan produktivitas kerja (Hanaysha, 2016).

Berdasarkan penjelasan-penjelasan tersebut dapat diketahui bahwa kinerja dipengaruhi oleh komitmen ataupun keterikatan dengan lingkungan kerja dan penilaian petugas maupun kader terhadap kepuasan kerjanya, meskipun pengetahuan, modal psikologis, peran pemerintah dan hal lainnya turut berkontribusi namun tidak secara keseluruhan.

\section{Kesimpulan dan Saran}

Komitmen dan kepuasan kerja dapat meningkatkan kinerja kader puskesmas. Komitmen terhadap peran diri dan organisasi mempengaruhi peningkatan kinerja kader puskesmas dalam memenuhui beban tugasnya. Persepsi terhadap kepuasan kerja juga dipengaruhi terhadap apresiasi dan insentif yang diberikan organisasi atau puskesmas pada Kader.

Adanya peran aktif kader menunjukkan kinerja kader dan implementasi terhadap komitmen diri maupun komitmen kerja berkaitan dengan
Puskesmas. Komitmen kader terlihat dalam komitmen afektifnya terhadap organisasi dimana kinerja kader yang meningkat tidak hanya berdasarkan insentif, namun adanya pengembangan diri dan peningkatkan pengetahuan akan meningkatkan kinerja kader. Berbagai faktor yang dapat mempengaruhi kinerja kader secara teoritis dapat dijadikan acuan untuk meningkatkan kinerja kader secara riil dilapangan. Hal ini dikarenakan kader merupakan sistem dasar dalam lingkup puskesmas yang dapat membaur dan menyatu dengan masyarakat tanpa adanya jarak sosial.

\section{Daftar Pustaka}

Adeniji, A. A,, Osibanj, A. O., Iruonagbe, T.C., Olawande, T.,, Ibidunni, A., S., \& Olokundun, M. A. (2019). From Job Satisfaction to Organizational Commitment: The Mediating Influence of Perceived Treatment of Diversity among Nigeria's Public Healthcare Employees. Macedonian Journal of Medical Sciences, 7(12), 2031-2035.

Akintola, O \& Chikoko, G. (2016). Factors influencing motivation and job satisfaction among supervisors of community health workers in marginalized communities in South Africa. Human Resource for Health, Vol 14 (54), 1-15. Doi: 0.1186/s12960-016-0151-6

Bahri, MS. (2018). Pengaruh Kepemimpinan, Lingkungan Kerja, Budaya Organisasi, dan Motivasi Terhadap Kepuasan Kerja yang Berimplikasi terhadap Kinerja Dosen. Surabaya: Jakad Publishing

Bidayati, U. (2017). Commitment, Motivation and Performance of Posyandu Cadres. Advances in Intelligent Systems Research, 131, DOI: 10.2991/icoi-17.2017.27

Bonenberger, M., Aikins, M., Akweongo, P. \& Wyss, K. (2014). The effects of health worker motivation and job 
satisfaction on turnover intention in Ghana: a cross-sectional study. Human Resource for Health, Vol 12 (43), 1-12.

Choi, S. (2013). Demographic diversity of managers and employee job satisfaction: Empirical analysis of the federal case. Review of Public Personnel Administration, 33(3):275-98.

Fattah, A. H. (2017). Kepuasan Kerja dan Kinerja Pegawai. Yogyakarta: Elmatera

Farooqui, M. S., \& Nagendra, A. (2014). The Impact of Person Organisation Fit on Job Satisfaction and Performance of the Employees. Procedia Economics and Finance, 11 (14), 122-129.

Geldsetzer, P., De Neve, J.W., Boudreaux, C., Bärnighausen, T., \& Bossert., T. J. (2017). Improving the Performance of Community Health Workers in Swaziland: Findings from a Qualitative Study. Human Resources for Health, Vol 15 (1), 1-9 doi:10.1186/s12960-017-0236-x.

Ghozali, DA. (2015). Buku 4 Kader Desa: Penggerak Prakarsa Masyarakat Desa. Jakarta: Kementerian Desa, Pembangunan Daerah Tertinggal, dan Transmigrasi Republik Indonesia

Guan, C. Y. S, Li, Y \& Ma, H. L. (2017). Cadres Competence In CommunityBased Management Of Child Illness In Banyumas District, Central Java, Indonesia. Belitung Nursing Journal, 4(5), 492-501.

Hadiyanta, T. H, Istiono, W., Pramantara, I. D. P. (2018) Impact of training by family doctor on cadre performance in counseling at Posbindu Dusun Tahunan of Gunungkidul regency. Review of Primary Care Practice and Education. Vol 1(1): 31-36.
Hamirul. (2016). Perilaku Organisasi Cianjur: Universitas Putra Indonesia

Hanaysha. J. (2016). Testing the Effects of Employee Empowerment, Teamwork, and Employee Training on Employee Productivity in Higher Education Sector. International Journal of Learning and Development. 6(1). 164-178

Husniyawati, Y. R.,Widacahya, F., \& Wulandari, R. D. (2020). The most important component of organizational commitment contributes to increase integrated performance at integral service post in Indonesia. EurAsian Journal of BioScience (14), 2721-2725.

Kisumbe, L. A \& Mashala, L. Y. (2020). The Influence of Human Resource Practices on Job Satisfaction in Decentralized Health Service Delivery: A Case of Shinyanga Region in Tanzania. Journal of Human Resource Management, Vol 8(3), 190 -199. Human Resource for Health, Vol 11 (2), 1-5.

Kristiarini, J.J., Syamsulhadi, H.M., Kusnandar, \& Sulaeman, E. S. (2020). Empowerment of Family Planning (FP) Cadres and Influencing Factors with SEM Analysis. Indian Journal of Public Health Research \& Development, Vol 11 (7), 311 - 317.

Kumar, R., Shaikh, J., Hafeez, B. T \& Hafeez, A. (2013). Job satisfaction among public health professionals working in public sector: a cross sectional study from Pakistan.

Lefevre, dkk (2015). Profile, knowledge, and work patterns of a cadre of maternal, newborn, and child health CHWs focusing on preventive and promotive services in Morogoro Region, Tanzania. Human Resources for Health, Vol 13 (98), 1-14. 
Merga, H. \& Fufa, T. (2019). Impacts of working environment and benefits packages on the health professionals' job satisfaction in selected public health facilities in eastern Ethiopia: using principal component analysis. BMC Health Services Research, Vol 19 (494). doi.org/10.1186/s12913019-4317-5

Musinguzi, C., Namale, L., Rutehemberwa, E., \& Dahal, A. (2018). The relationship between leadership style and health worker motivation, job satisfaction and teamwork in Uganda. Journal of Healthcare Leadership, Vol 10, 28-32.

Noermijati. (2013). Kajian Tentang Aktualiasi Teori Herzberg, Kepuasan Kerja dan Kinerja Manajer Operasional. Malang: UB Press

Novita, BSS; Ruhana, I. (2016). Pengaruh Kepuasan Kerja dan Komitmen Organisasional Terhadap Kinerja Karyawan. Jurnal Administrasi Bisnis (JAB). Vol 34. No.1. Mei 2016. Hal: 38-46

Pangetuti, R., Dewi, Y., L. R., \& Sulaeman E, S. (2020). Contextual Factors of Posyandu on Cadre Performance in Providing Maternal and Child Health Service in Surakarta, Central Java. Journal of Maternal and Child Health, Vol 5(1): 27-34.

Prihantoro, A. (2015). Peningkatan Kinerja Sumber Daya Manusia Melalui Motivasi, Disiplin, Lingkungan Kerja, dan Komitmen. Yogyakarta: Deepublish

Robbins, S. P \& Judge, T. A. (2010). Perilaku Organisasi Edisi 12. Jakarta: Salemba

Sholikhah, U., Kusnanto, H., Hariyanti F., \& Purbandari, Y.. (2018). Cadres Competence In Community-Based Management Of Child Illness In Banyumas District, Central Java,
Indonesia. Belitung Nursing Journal, 4(5), 492-501

Sihombing, K., Kandarina, B. I., \& Sumarni, S. (2016). Peran lurah, petugas kesehatan, dan kader dalam partisipasi ibu balita ke posyandu di wilayah cakupan D/S terendah dan tertinggi di Kota Jambi. Jurnal Gizi dan Dietetik Indonesia (Indonesian Journal of Nutrition and Dietetics), 3(2), 87-97.

ST-Hilaire, W. A., \& de la Robertie, C. (2018). Correlates of affective commitment in organizational performance: Multi-level perspectives. Australian Journal of Career Development, 27(1), 38. doi:10.1177/1038416217744215

Sukmawati, \& Gani, N. (2014). Pengaruh Kecerdasan Emosional, Kepuasan Kerja, dan Komitmen Organisasi Terhadap Kinerja Karyawan pada Koperasi Karyawan PT. Telkom Siporennu Makasar. Jurnal Manajemen dan Akuntansi, Vol. 3, No. 3, Desember 2014. Hal: 15-29

Wahono, RS. (2016). Systematic Literature Review: Pengantar, Tahapan, dan Studi Kasus. https:/ romisatria wahono .net/ 2016/ 05 15/systematic-literaturereview- pengantar-tahapan-dan-studikasus/

Wirapuspita, R.(2013). Insentif dan kinerja kader posyandu. Kemas: Jurnal Kesehatan Masyarakat, 9(1), 58-65. 